\title{
Feminist Futures: Celebrating Diversities, Asserting Rights, Transforming Societies, Reinventing Economies
}

\author{
Stefano Prato ${ }^{1}$
}

Published online: 14 May 2018

(C) Society for International Development 2018

In accordance with past tradition, ${ }^{1}$ this issue of the Journal celebrates the 13th AWID International Forum, which brought together in Brazil over 1800 feminists and women's rights advocates in a spirit of resistance and resilience. As Guest Editor Rochelle Jones masterfully articulates the content of the issue in her Guest Editorial, let me devote this short piece to a few additional considerations.

The Brazil Forum as well as the articles in this Journal show that, while there is much to celebrate, the path to address the deep systemic roots of patriarchy remains long and complex.

In this context, my first reflection aims to challenge the conventional notion that women's empowerment is smart economics, promoted by many mainstream institutions seeking to ride the potential growth dividend of greater women's economic inclusion. This is highly problematic on several fronts. Most importantly, this narrative undermines the primacy of women's human rights and subsumes their fulfilment to the logic of economic gain and efficiency. Affirming women's rights and ensuring gender equality requires public policies and comprehensive fiscal measures, including progressive taxation regimes and gender-responsive public budgets. Placing economic efficiency at the cornerstone of such policies may stimulate cost-benefit analyses rather than rights-based rationales for public agency. At macro-economic level, unpaid domestic and care work derived from the sexual division of labour continue to represent the single largest subsidy to the global economy, exposing the systemic foundations of

Stefano Prato

stefanop@sidint.org

Society for International Development (SID), Rome, Italy patriarchy and the macro obstacles to fulfil women's human rights. It is therefore evident how financial crises made matters worse for women, not only because the care burden increased but also because they were primarily and often inequitably impacted by austerity measures. Indeed, women lives and bodies, due to the multiple productive, reproductive and care roles, provided the most significant counter-cyclical support during financial crises despite the multidimensional gendered impact of fiscal policy responses. Hence the need to problematize the continuous attempts to exclusively localize the discussion at the microlevel (i.e. women's entrepreneurship) while at the same time increasing the policy bias in favour of privatization, private delivery of public services and use of scarce public resources to incentivize, risk-indemnify and leverage private investments. Not only does this further undermine the State's capacity to regulate the market to realign the production and marketing model and truly advance the structural transformations to tackle the root cause of inequalities. But it further consolidates the capture of the public space by powerful elites, consolidating current power asymmetries and facilitating the continued concentration of political and economic power. It is in this context that we experience the emergence of normative hierarchies between investors' and other commercially framed rights, on one hand, and human rights on the other, which weaken the State's capacity to respect, protect and fulfil women's human rights.

My second reflection aims to contrast the notion that gender equality is primarily generated by socio-economic policies. Of course, socio-economic policies matter. But, as

\footnotetext{
1 Development Journal issues on Women's Rights and Development, Vol 49(1) (2006); Power, Movements, Change, Vol 52(2) (2009); Gender and Economic Justice Volume 55(3) (2012).
} 
I have articulated in previous editorials, multidimensional analyses of inequalities expose the evidence that some social groups are more likely to suffer multiple inequalities, hence highlighting the existence of power structures within society. Indeed, gender inequalities, the most pervasive and deeply rooted form of inequalities, can only be tackled by placing the analysis of power structures at the core and unveiling of the political economies that ensure the preservation of patriarchy. This is even more important if the intersections between race, gender and class, as well as other sociocultural determinants that limit access to services and resources, are taken into account and gender is therefore understood in such broader context of intersectionality. This moves away from the design of social and economic policies, no matter how important they remain, to focus on how to catalyze processes of political and cultural change that can lead to systemic redesigns and rebuilding of our societies and their broken social relations and ecological foundations. It is precisely in the context of such power analyses that bodily integrity claims a central space against the attempt to relegate it to the margins. Indeed, the regressive political climate and renewed identity-politics are often reinforcing sexual and gender-based violence, rooted in patriarchal gender norms and unequal power relationships. Physical, emotional, psychological or sexual violence is further reinforced by the commodification of female bodies and the new challenges generated by digitalization and dematerialization. Body politics, the political struggle of people to claim control over their own biological, social and cultural 'bodily' experiences, is therefore central to the reclaiming of power and the tackling of the political economies of inequalities.

My third reflection is rather a corollary of the previous two: feminist organizing is the cornerstone of change, precisely because of the urgent need to catalyze political and cultural transitions. Human rights, including women's rights, are established by people and their communities, not by laws, though laws can recognize their existence and establish legal justiciability for their violations. And no rights can exist without celebration and affirmation of the value of diversity. As power never concedes without a demand, laws and socio-economic policies will always follow and never lead. By celebrating diversities and asserting women's rights and sexual rights, it is therefore feminist organizing that is transforming our societies and reinventing our economies. Hence, the important contribution of the AWID Forum and the small tribute that this Journal issue intends to represent.

Because no change is possible without feminism, and there is no feminism without change. 